\title{
Developmental Aspects of $\beta$-Adrenergic Receptors and Catecholamine-Sensitive Adenylate Cyclase in Rat Myocardium
}

\author{
JEFFREY A. WHITSETT ${ }^{(30)}$ AND CHARLOTTE DAROVEC-BECKERMAN \\ Newborn Division of Pediatrics, University of Cincinnati College of Medicine, Cincinnati, Ohio, USA
}

\begin{abstract}
Summary
The ontogeny of $\beta$-adrenergic receptors and the characteristics of catecholamine sensitive adenylate cyclase activity were demonstrated in rat ventricular myocardium. $\beta$-Adrenergic receptors were identified by the binding of $(-)-\left.\right|^{3} \mathrm{H} \mid \mathrm{dihydroalprenolol}$, $\left[(-)-\left.\right|^{3} \mathrm{H} \mid \mathrm{DHA}\right]$, and $\left.( \pm)-\left.\right|^{125} \mid\right]$ iodohydroxy-benzylpindolol, $( \pm)-$ ${ }^{125}[$ I]HYP. Heart weight, protein, and the number of $\beta$-adrenergic receptors per cell increased with advancing age; however, binding capacity $\left(B_{\max }\right)$ per $\mathrm{mg}$ protein was lower in membrane from the adult rat $(220 \mathrm{~g}$ body weight) than in membrane from the fetal or neonatal rat, $36.8 \pm 4.1$ and $58.3 \pm 6.3 \mathrm{fmoles} \cdot \mathrm{mg}^{-1}$ protein, respectively, mean $\pm \mathrm{SE}, P<0.01$. The age-dependent increase in the numbers of receptors per heart correlated well with the increases in ventricular weight. In contrast, protein content, $\mathrm{Na}^{+}$, $\mathrm{K}^{+}$-ATPase, 5'-nucleotidase, and adenylate cyclase content increased more rapidly than ventricular weight, and the developmental increase in $\left[^{3} \mathrm{H}\right]$ DHA binding sites (per heart) did not keep up with increases in ventricular protein. Although specific activity of $(-)-\left[{ }^{3} \mathrm{H} \mid \mathrm{DHA}\right.$ binding was lower in the adult ventricle, the characteristics of the $\beta$-receptor did not vary with age; the subtype was $\beta_{1}$ determined by classical agonist competition in fetal and adult ventricular membranes and the $\beta_{1}$ - and $\beta_{2}$-adrenergic receptor subtypes were present in the ratio of $75 \% \beta_{1}$ and $25 \% \beta_{2}$ in both fetal and adult samples. Guanine nucleotides decreased agonist affinity for the inhibition of $( \pm)-\left.\right|^{125} I \mid H Y P$ binding equally in adult and fetal samples and enhanced the activation of adenylate cyclase by catecholamine. Basal adenylate cyclase activity was significantly higher in weanling, $13.4 \pm 1.42$, and adult, $14.2 \pm 5.8$, than in 21-day fetal or newborn ventricular membrane, 8.18 \pm 1.5 pmoles cyclic adenosine $3^{\prime}: 5^{\prime}$-monophosphate produced $\mathrm{mg}^{-1}$. $\min ^{-1}($ mean \pm S.D.). The percent activation by catecholamine (with and without GTP) was also slightly higher in samples from the older rats, $P<0.01$. In the adult and weanling heart, both guanine triphosphate (GTP) and guanyl-5'-yl-imidodiphosphate [Gpp(NH)p] were effective in enhancing catecholamine sensitive activity. Maximal catalytic activation of adenylate cyclase was observed in the presence of $(-)$-epinephrine and $\mathrm{Gpp}(\mathrm{NH}) \mathrm{p}$ and was significantly higher (fold stimulation) in fetal or neonatal ventricular samples as compared to adult or weanling ventricular samples, $P<0.01$.
\end{abstract}

\section{Speculation}

The decreased specific activity (per mg protein) of $\beta$-adrenergic receptors in adult as compared to fetal and neonatal myocardium may therefore be related to the decreasing proportion of sarcolemmal protein versus total and particulate cell protein which occurs during hypertrophic cardiac growth, supporting the hypothesis that sarcolemmal surface area is a major determinant of $\beta$-receptor number. In contrast, sarcolemmal activities which mediate cellular functions by regulating the concentration of various substances within the cell, such as $\mathrm{Na}^{+}, \mathrm{K}^{+}$-ATPase, and adenylate cyclase, increased to a greater extent than $(-)-\left[^{3} \mathrm{H}\right] \mathrm{DHA}$ binding, and were more directly proportional to cell protein. The function and affinity of these $\beta$-adrenergic receptors in the rat myocardium are mediated by guanine nucleotides early in development, and agedependent differences in the activation of catecholamine sensitive adenylate cyclase by GTP and Gpp(NH)p may relate to developmental differences in the properties of guanine nucleotide-dependent factors which mediate receptor occupancy and cyclic adenosine 3':5'-monophosphate formation.

The effects of catecholamines on heart rate and contractility are thought to be mediated by their interactions with $\beta$-adrenergic receptors present on the sarcolemmal membrane and the stimulation of adenylate cyclase activity. Catecholamines stimulate heart rate, inotropy, or adenylate cyclase early in the development of the human, rat, and chick myocardium; however, the characteristics of $\beta$-adrenergic receptors and their interaction with adenylate cyclase have not been directly studied in the fetal and neonatal mammal $(1,6,7,14,17)$. Although a recent study demonstrated that $\beta$-adrenergic antagonist binding in the rat myocardium increased with advancing age (2), the factors regulating the numbers and function of $\beta$-adrenergic receptors as well as the concentrations of other sarcolemmal activities during growth and maturation of the myocyte are not well defined. Similarly, the interactions between the $\beta$-adrenergic receptor and guanine nucleotides has not been directly studied in fetal and neonatal myocardium.

The relationship between $\beta$-adrenergic receptor sites and adenylate cyclase is now known to be mediated by guanine nucleotides and guanine nucleotide-dependent factors which are required for the activation of adenylate cyclase in purified membranes (12, $13,19)$, and the effects of $\mathrm{Gpp}(\mathrm{NH}) \mathrm{p}$ on catecholamine-sensitive adenylate cyclase have in fact been recently characterized in the fetal rat myocardium (6). Guanine nucleotides interact with the receptor-adenylate cyclase system at two or more sites; at the receptor site, GTP decreases agonist potency for receptor binding, and at the catalytic subunit of adenylate cyclase, guanine nucleotides are required for activation $(12,13)$. In the pigeon erythrocyte, GTP is hydrolyzed by a specific hormone-sensitive GTPase which is stimulated by catecholamines (5). Gpp(NH)p and other nonhydrolyzable analogues of GTP irreversibly activate the catalytic subunit in a time dependent process which is enhanced by the presence of agonist (catecholamine) (4-6, 12). Although a synergistic effect of guanine nucleotides on catecholamine and glucagon sensitive adenylate cyclase in developing rat myocardium has been recently demonstrated $(6,27)$, previous developmental studies of catecholamine-sensitive adenylate cyclase and its relation to $\beta$ adrenergic receptors in the myocardium have not included the role of guanine nucleotides at either the receptor site or at the catalytic site.

The present study was therefore designed to demonstrate: (1) the relationships among heart weight, cell number, protein content, and the sarcolemmal activities $\mathrm{Na}^{+}, \mathrm{K}^{+}$-ATPase, $\beta$-adrener- 
gic receptor binding, and adenylate cyclase during growth and maturation of the rat myocardium; (2) the presence and characteristics of $\beta$-adrenergic receptor sites in the fetal and adult rat ventricular myocardium; (3) their relationships to adenylate cyclase activity; and (4) the modulation of $\beta$-adrenergic receptor affinity by guanine nucleotides which are required for the maximal activation of catecholamine sensitive adenylate cyclase.

\section{MATERIALS AND METHODS}

$\left[{ }^{3} \mathrm{H}\right] \mathrm{cAMP},\left[\alpha^{-32} \mathrm{P}\right] \mathrm{ATP},( \pm)-\left[{ }^{125} \mathrm{I}\right] \mathrm{HYP}(2200 \mathrm{Ci} / \mathrm{mmole})$, and $(-)-\left[{ }^{3} \mathrm{H}\right] \mathrm{DHA}$ (56 Ci/mmole) were purchased from New England Nuclear Corp. Catecholamines, calf thymus DNA, and other reagents were purchased from Sigma Chemical Co. Gpp(NH)p was obtained from ICN (Chicago, IL). (-)-Propranolol, and (+)propranolol were obtained from Ayerst Co. Metoprolol was a generous gift of Ciba-Geigy Corp., and zinterol from the MeadJohnson Corp.

\section{MEMBRANE PREPARATION}

Timed pregnant Sprague-Dawley rats were sacrificed by cervical dislocation on day 21 of gestation or within $24 \mathrm{hr}$ of birth. The fetuses or pups from each litter were immediately sacrificed by decapitation; ventricle was dissected from atrium and vessels and placed in iced $250 \mathrm{mM}$ sucrose, $1 \mathrm{mM}$ ethylene glycol bis $(\beta$ aminoethyl ether)- $N, N^{\prime}$-tetraacetic acid:5 mM Tris-HCl (pH 7.4). Pooled (10 to 14 per litter) samples were homogenized in 20 volumes of buffer per tissue weight by three 5 -sec bursts with a Tekmar Tissuemizer homogenizer (Cincinnati, OH). Samples were taken for protein and DNA determinations. The remaining homogenate was poured through four layers of gauze and centrifuged $30,000 \times g$ for $10 \mathrm{~min}$. The pelleted samples were resuspended in an equal volume of the iced buffer and centrifuged again 30,000 $\times g$ for $10 \mathrm{~min}$. This pellet was resuspended to final membrane protein concentration of 2 to $5 \mathrm{mg} / \mathrm{ml}$, frozen in dry ice acetone, and stored at $-80^{\circ} \mathrm{C}$ before assay. Young male ( 80 to $90 \mathrm{~g}$ ) and adult male (approximately $220 \mathrm{~g}$ ) rat ventricular membranes were prepared from individual Sprague-Dawley rats as described for the fetal samples with identical wash procedures. Further washes or membrane purification result in a loss of hormone sensitivity. Adult and fetal samples were prepared or assayed together on each work day.

\section{BINDING ASSAYS}

$(-)-\left[{ }^{3} \mathrm{H}\right]$ DHA binding was determined as previously described in a $250 \mu \mathrm{l}$ assay containing 200 to $300 \mu \mathrm{g}$ protein, $10 \mathrm{mM} \mathrm{MgCl}_{2}$, and 0.2 to $5 \mathrm{nM}(-)-\left[{ }^{3} \mathrm{H}\right] \mathrm{DHA}, 50 \mathrm{mM}$ Tris- $\mathrm{HCl}(\mathrm{pH} 7.4)(23,25$, 26). Binding was assessed in triplicate by filtration assay after 20 min incubation at $30^{\circ} \mathrm{C}$; the assay was terminated by filtration through glass fiber filters and washed five times with $4 \mathrm{ml}$ of iced buffer. Nonspecific binding was also assessed in triplicate in the presence of $1 \mu \mathrm{M}( \pm)$ propranolol. $( \pm)-\left[{ }^{125} \mathrm{I}\right] \mathrm{HYP}$ binding was also utilized to determine $\beta$-adrenergic receptor subtypes because of its increased sensitivity, essentially as described by Hegstrand et al. (9) in $10 \mathrm{mM} \mathrm{MgCl}, 50 \mathrm{mM}$ Tris- $\mathrm{HCl}(\mathrm{pH}$ 7.4) buffer in the presence and absence of $100 \mu \mathrm{M}$ GTP. The protein concentration ranged from 30 to $40 \mu$ g per assay, and the $( \pm)-\left[{ }^{125} \mathrm{I}\right] \mathrm{HYP}$ concentration was varied from 25 to $300 \mathrm{pM}$ for Scatchard analysis. The assay was incubated at $37^{\circ} \mathrm{C}$ for 30 to $50 \mathrm{~min}$, was terminated by rapid filtration on glass fiber filters, and was washed three times with $4 \mathrm{ml}$ of the incubation buffer at $37^{\circ} \mathrm{C}$. Specific binding is defined with either ligand and was proportional to membrane protein under these conditions. $\beta_{1^{-}}$and $\beta_{2}$-adrenergic subtypes were estimated from the analysis of Hofstee plots of the inhibition of $( \pm)-\left[{ }^{125} I\right] H Y P$ binding by zinterol as previously described $(15$, 25).

\section{ADENYLATE CYCLASE AND MARKER ENZYMES}

Adenylate cyclase was determined at $30^{\circ} \mathrm{C}$ in triplicate by a modification of the method of Salomon et al. $(20,23)$. The assay contained 50 to $75 \mu \mathrm{g}$ protein, $0.2 \mathrm{mM}\left[\alpha-{ }^{32} \mathrm{P}\right] \mathrm{ATP}(2 \mu \mathrm{Ci}), 3.0$ $\left.\mathrm{mM} \mathrm{MgCl} 2,1.0 \mathrm{mM} \mathrm{[}{ }^{3} \mathrm{H}\right] \mathrm{cAMP}(0.01 \mu \mathrm{Ci}), 100 \mathrm{mM}$ Tris- $\mathrm{HCl}(\mathrm{pH}$ 7.4), a creatine phosphokinase-phosphocreatine regenerating system, $0.1 \%$ bovine serum albumin, $12.5 \mathrm{mM}$ sucrose, $0.05 \mathrm{mM}$ EGTA, and added hormone and guanine nucleotide. The assay mixture was preincubated for $5 \mathrm{~min}$ at $30^{\circ} \mathrm{C}$, and the reaction was initiated by the addition of labeled ATP. Basal and hormonestimulated cAMP production was entirely linear for at least 30 min, and triplicate determinations usually varied less than $5 \%$. Column recoveries of $\left[{ }^{3} \mathrm{H}\right] \mathrm{cAMP}$ varied from 60 to $75 \%$ and were not altered by theophylline. $\mathrm{Na}^{+}, \mathrm{K}^{+}$-ATPase (EC 3.6.1.3) was determined by a spectrophotometric method as previously described in the presence of $5 \times 10^{-3} \mathrm{M}$ ouabain at $37^{\circ} \mathrm{C}$, and $5^{\prime}$ nucleotidase (EC 3.1.3.5) was determined in the presence of $\mathrm{Na}^{+}$, $\mathrm{K}^{+}$tartrate $(10 \mathrm{mM})$ at $37^{\circ} \mathrm{C}(25)$. DNA was determined by the method of Schneider with cali thymus DNA (Sigma Chemical Co.) as standard (21). Statistical significance was determined by Student's $t$ test of enzyme activity or binding capacity. Fold stimulation represents adenylate cyclase activity divided by basal activity; catecholamine-stimulated activity is that increase in activity over the appropriate control basal activity, related to the addition of $5 \times 10^{-5} \mathrm{M}(-$ )epinephrine.

\section{RESULTS}

\section{CHARACTERISTICS OF VENTRICULAR GROWTH}

Ventricular weight increased 25.9-fold, nearly proportionately to body weight in rats from birth to $217 \mathrm{~g}$ body weight (Table 1). Protein content increased in great excess of either weight or DNA content as hypertrophy became the major determinant of ventricular growth especially between 91 and $217 \mathrm{~g}$ body weight. Particulate protein, of which sarcolemmal protein is a small component, represented $40 \%$ of total ventricular protein, and this proportion did not change with age. The specific activity and total recovered activity (per ventricle) of $\beta$-adrenergic receptors, $\mathrm{Na}^{+}, \mathrm{K}^{+}$-ATPase, and $5^{\prime}$-nucleotidase are compared in Table 2 . When expressed as specific activity (per mg protein), $(-)-\left[{ }^{3} \mathrm{H}\right] \mathrm{DHA}$ binding decreased progressively with age whereas the specific activity of the other membrane markers increased or remained relatively constant. $\beta$ Adrenergic receptors per heart increased nearly proportionately to ventricular weight but did not keep up with developmental increases in total or particulate protein content (Tables 1 and 2). Both basal and maximally activated adenylate cyclase activity increased with age in excess of the numbers of $\beta$-adrenergic receptors or in ventricular weight as shown in Table 2 .

\section{IDENTIFICATION OF $\beta$-ADRENERGIC RECEPTOR}

$(-)-\left[{ }^{3} \mathrm{H}\right] \mathrm{DHA}$ bound to particulate fractions of fetal and adult myocardium with properties characteristic of binding to a $\beta$ adrenergic receptor. Specific binding was rapid, reaching equilibrium by $20 \mathrm{~min}$ at $30^{\circ} \mathrm{C}$ at the lowest ligand concentration. Binding was rapidly reversible and was stereoselective for the $(-)$-stereoisomer of propranolol. Agonist competition followed the order of potency $(-)$-isoproterenol $>(-)$-norepinephrine $=(-)$ epinephrine. $(-)-\left[{ }^{3} \mathrm{H}\right] \mathrm{DHA}$ binding $\left(\mathrm{B}_{\max }\right)$ was higher in fetal $(52$ $\left.\pm 5.5 \mathrm{fmoles}^{-1} ; n=5\right)$ and neonatal myocardium $(58.3 \pm 11.0$ fmoles $\left.\cdot \mathrm{mg}^{-1}\right)$ than in the mature adult myocardium (36.8 \pm 7.1 fmoles. $\mathrm{mg}^{-1}$; mean \pm S.D.), protein as shown in Table 2 and Figure 1. The affinity of $(-)-\left[{ }^{3} \mathrm{H}\right] \mathrm{DHA}$ for the receptor was similar in myocardial membranes from the adult, neonate, and fetus (approximately $2.0 \mathrm{nM}$ ). The higher specific activity for binding in the fetal heart was confirmed in saturation studies with the antagonist $( \pm)-\left[{ }^{125} I\right] H Y P$. Binding of $( \pm)-\left[{ }^{125} I\right] H Y P$ also appeared to occur to a single class of sites in both fetal and adult sample, $\mathrm{K}_{\mathrm{D}}$ approximately $150 \mathrm{pM} .( \pm)-\left[{ }^{125} \mathrm{I}\right] \mathrm{HYP}$ binding was also higher in the fetal than in the adult rat myocardium (Fig. 2). Although the number of sites was slightly lower in these experiments, the relative differences in $B_{\max }$ between adult and fetal ventricular myocardium were maintained. 
Table 1. Characteristics of ventricular growth, protein, particulate protein and DNA in developing rat heart. ${ }^{1}$

\begin{tabular}{|c|c|c|c|c|c|c|}
\hline Body wt (g) & $\begin{array}{c}\text { Wt. per } \\
\text { ventricle }(\mathrm{g})\end{array}$ & $\begin{array}{c}\text { Protein per } \\
\text { ventricle }(\mathrm{mg})\end{array}$ & $\begin{array}{c}\text { DNA per } \\
\text { ventricle }(\mathrm{mg})\end{array}$ & $\begin{array}{l}\text { Protein } \\
\text { DNA } \\
\left(\frac{m g}{m g}\right)\end{array}$ & $\begin{array}{c}\text { Membrane } \\
\text { protein per } \\
\text { ventricle }(\mathrm{mg})\end{array}$ & $\begin{array}{l}\text { Particulate } \\
\text { protein } \\
\text { (\% recovery) }\end{array}$ \\
\hline $91.0 \pm 5.89(n=4)$ & $\begin{array}{c}0.28 \pm 0.03 \\
\quad(12.7)\end{array}$ & $\begin{array}{c}64.3 \pm 7.68 \\
(20.9)\end{array}$ & $1.18 \pm 0.03$ & 54.5 & $\begin{array}{c}23.1 \pm 1.81 \\
(17.6)\end{array}$ & 36 \\
\hline
\end{tabular}

${ }^{1}$ Animals from four litters were obtained on the day of birth; juvenile and adult samples were taken from male Sprague-Dawley litter mates at approximately 30 and 60 days of age, respectively. Ventricle was dissected from atria and major vessels, pooled from four to five litter mates in the neonatal pups, and processed from individual hearts in the older samples as described in "Materials and Methods."

${ }^{2}$ Mean \pm S.D.

${ }^{3}$ Numbers in parentheses, fractional change using the values from the $7.25 \mathrm{~g}$ pups as unity.

Table 2. Specific activity and total recovered activity of $\beta$-adrenergic receptors, adenylate cyclase, and plasma membrane markers in the developing rat ventricle. ${ }^{1}$

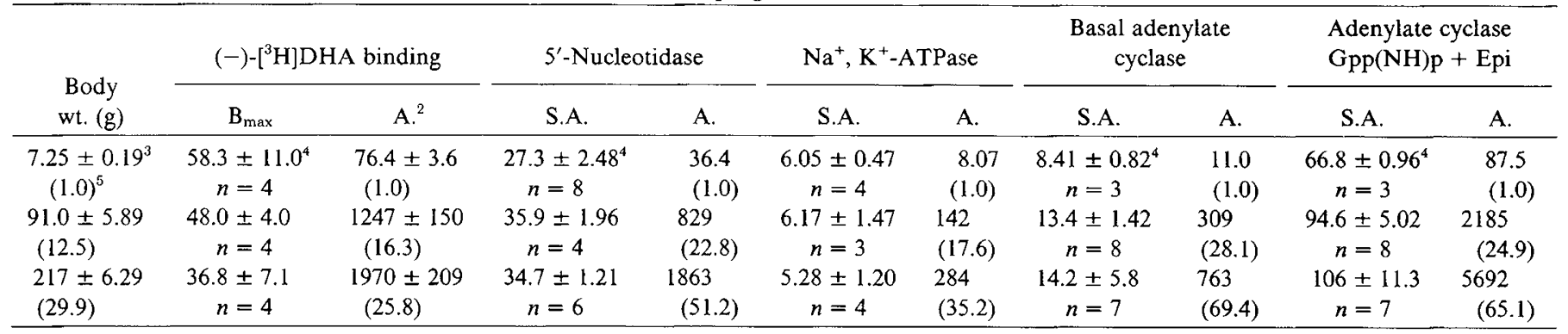

${ }^{1}(-)-\left[{ }^{3} \mathrm{H}\right] \mathrm{DHA}$ binding represents $\mathrm{B}_{\max }$ from individual Scatchard analyses. 5'-Nucleotidase (nmoles $\left.\mathrm{mg}^{-1} \mathrm{~min}^{-1}\right), \mathrm{Na}^{+}, \mathrm{K}^{+}-\mathrm{ATPase}^{\prime}\left(\mu \mathrm{moles} \mathrm{mg}^{-1}\right.$. $\mathrm{hr}^{-1}$ ), and adenylate cyclase (pmoles $\cdot \mathrm{mg}^{-1} \cdot \mathrm{min}^{-1}$ ) were determined as described in "Materials and Methods." Maximal activation of adenylate cyclase was observed in all samples in the presence of $\mathrm{Gpp}(\mathrm{NH}) \mathrm{p}\left(5 \times 10^{-5} \mathrm{M}\right)$ and $(-)$-epinephrine $\left(10^{-5} \mathrm{M}\right)$. Specific activity was determined in three to eight samples, and the estimation of total activity was determined by multiplication of specific activity times recovered membrane protein.

${ }^{2} \mathrm{SA}$, specific activity; A, total recovered activity.

${ }^{3}$ Mean \pm S.D.

${ }^{4}$ Fetal $<$ adult; $P<0.01$.

${ }^{5}$ Numbers in parentheses, fractional increase in activity using the $7.25 \mathrm{~g}$ body weight animals as unity.
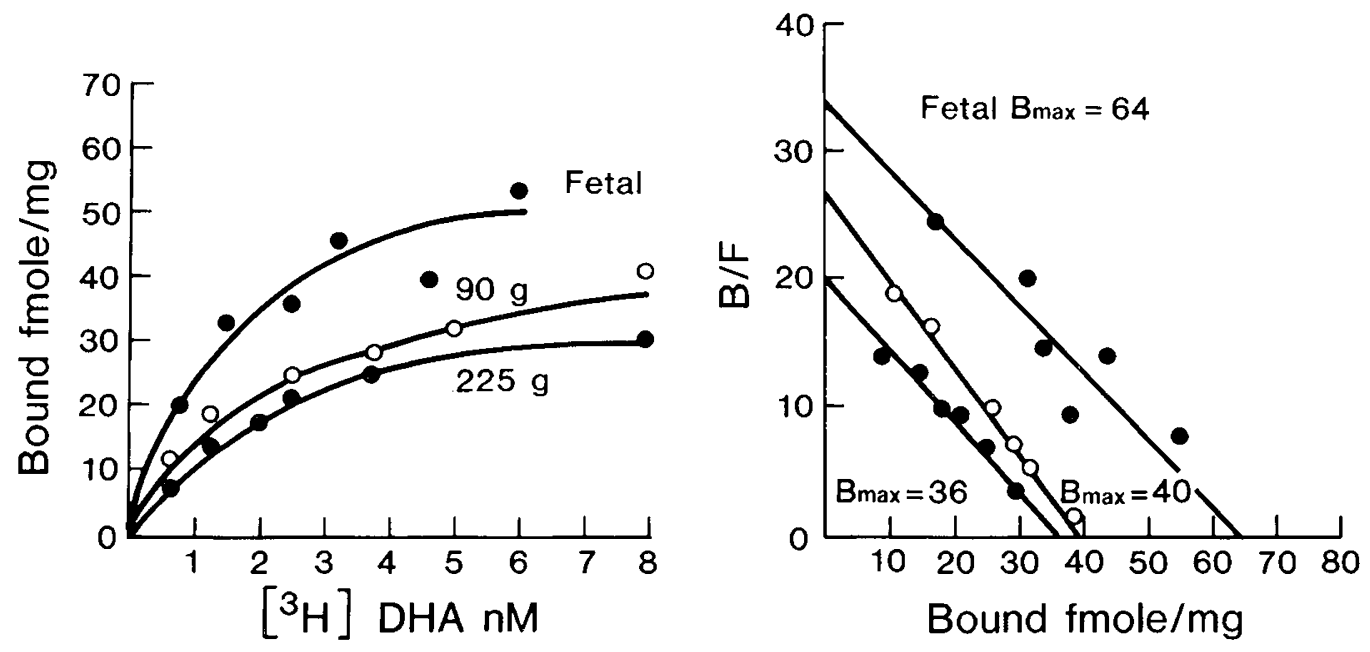

A

B

Fig. 1. Specific binding of $(-)-\left[{ }^{3} \mathrm{H}\right] \mathrm{DHA}$ to adult and neonatal rat ventricular myocardium. Total and nonspecific binding of (-)- $\left[{ }^{3} \mathrm{H}\right] \mathrm{DHA}$ was assessed in triplicate from myocardial membranes prepared from adult male rats $(220 \mathrm{~g})$ and from four litters (hearts were pooled) on the day of birth. Nonspecific binding was defined in the presence of $1 \mu \mathrm{M}(-)$ propranolol. The saturation data $(A)$ was analyzed by the method of Scatchard $(B)$. These curves are representative of four to five separate saturation experiments at each age. 


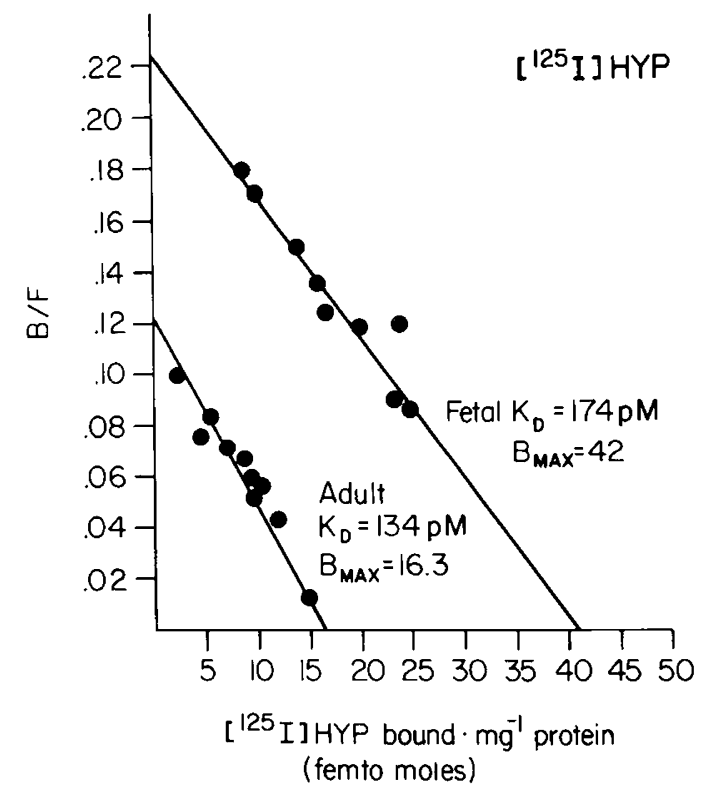

Fig. 2. ( \pm$)-\left[{ }^{125} I\right] H Y P$ binding to adult and fetal ventricular myocardium. Total and nonspecific binding was determined in triplicate in adult and fetal myocardium (obtained on day 21 of a 22-day gestation) as described in "Materials and Methods." The figure is representative of three similar experiments. Nonspecific binding was defined by $10 \mu \mathrm{M}$ $(-)$-isoproterenol.

\section{EFFECT OF GTP ON AGONIST AFFINITY}

Competiton of agonists for $( \pm)-\left[{ }^{125} \mathrm{I}\right] \mathrm{HYP}$ binding sites in fetal myocardium also followed the order of potency $(-)$-isoproterenol $>(-)$-norepinephrine $=(-)$-epinephrine (Fig. 3 ). The $\beta_{1}$-subtype was confirmed with the selective $\beta$-adrenergic agent zinterol (a $\beta_{2-}$ agonist) (Fig. 2) and with $\beta_{1}$-selective antagonist metoprolol (not shown). Analysis of their $( \pm)-{ }^{125}$ I]HYP inhibition curves revealed a $\beta_{1}: \beta_{2}$ subtype ratio of approximately $75 \% \beta_{1}: 25 \% \beta_{2}$ in fetal samples (Fig. 4). In the presence of GTP $\left(10^{-5} \mathrm{M}\right)$, agonist potency for (-)-isoproterenol was decreased approximately 10 -fold (Fig. 3 ). In addition, the slope of the curve describing the inhibition of $( \pm)-\left[{ }^{125} \mathrm{I}\right] \mathrm{HYP}$ binding was increased, and the Hill coefficient was increased to approximately 1.0 by the addition of GTP (not shown). This shift in potency relating to GTP occurred equally in adult and fetal samples.

\section{GUANINE NUCLEOTIDES AND ADENYLATE CYCLASE}

As shown in Tables 2 and 3, basal and maximal catalytic adenylate cyclase activity was higher in ventricular membranes of the adult and weanling rat than in the fetus or the neonate. The properties of adenylate cyclase were identical in weanling and adults samples (the latter are not shown in detail). Hormone sensitive adenylate cyclase activity in fetal and weanling ventricular myocardium are described in Table 3. Maximal catalytic activation was observed at both ages in the presence of $\mathrm{Gpp}(\mathrm{NH}) \mathrm{p}$ and (-)-epinephrine. Activation by (-)-epinephrine was enhanced by guanine nucleotide [either GTP or Gpp(NH)p] in all experiments. Epinephrine-stimulated adenylate cyclase (fold activation) was slightly higher in weanling than in fetal samples $(P<0.001)$. In contrast, maximal catalytic activation $(\mathrm{Gpp}(\mathrm{NH}) \mathrm{p}+(-)$-epinephrine) was higher in fetal than in the weanling samples $(P<$ $0.01)$. Catecholamine stimulation in all samples was enhanced by GTP or Gpp(NH)p, but exogenous guanine nucleotide was not required for stimulation by epinephrine, presumably due to residual GTP in these crude membrane preparations or to GTP present in commercial ATP. Guanine nucleotide enhancement of catecholamine stimulated adenylate cyclase was in fact diminished at higher ATP concentration ( $1 \mathrm{mM}$ ATP).

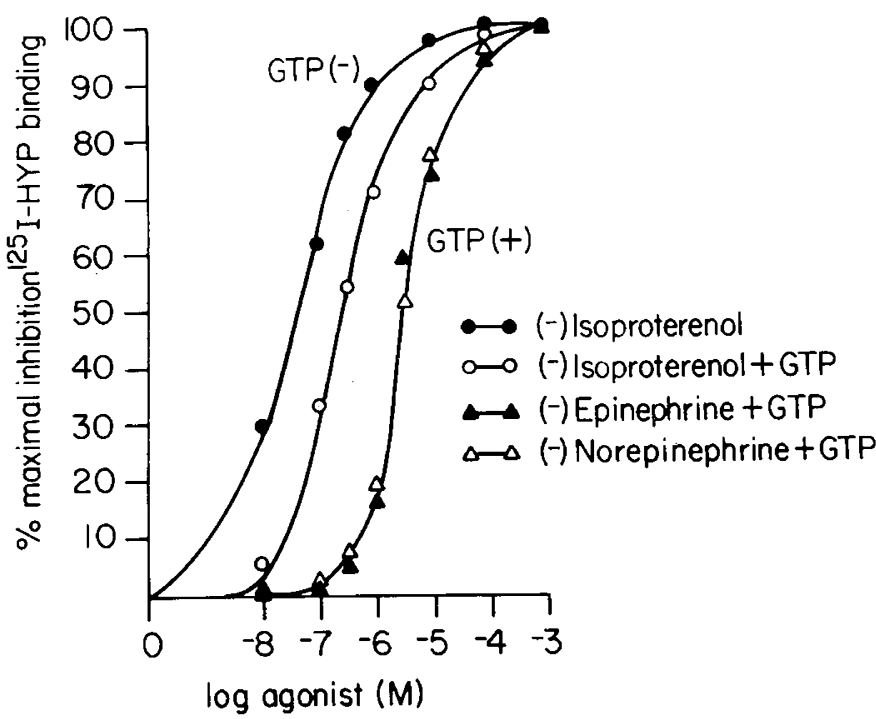

Fig. 3. Classical agonist inhibition of $( \pm)-\left[{ }^{125} \mathrm{I}\right] \mathrm{HYP}$ binding in fetal myocardium - effect of GTP. Specific $( \pm)-\left[{ }^{125}\right.$ I]HYP binding was assessed in triplicate in the presence and absence of $100 \mu \mathrm{M}$ GTP and increasing concentrations of $\beta$-adrenergic agonists $\left(10^{-8}\right.$ to $\left.10^{-3} \mathrm{M}\right)$. The figure is representative of at least two separate experiments with each agonist with fetal myocardium (day 21 of gestation). Experiments with adult male myocardial membrane $(217 \mathrm{~g})$ were identical and are not shown.

\section{EFFECTS OF GUANINE NUCLEOTIDES IN THE ABSENCE OF} CATECHOLAMINE

In the absence of hormone, $\mathrm{Gpp}(\mathrm{NH}) \mathrm{p}$ activated adenylate cyclase equally in the adult and fetal myocardium (Table 3). GTP activation in the absence of hormone was slightly but significantly higher in the fetal than adult $(P<0.01)$ membranes. The dose response curve, $K_{D}$, and maximal activation for guanine nucleotide were similar in the adult and fetus, and the dose response for fetal samples is represented by Figure 5. The effective concentration to achieve half-maximal activation for guanine nucleotides was approximately $10^{-7} \mathrm{M} \mathrm{GTP}$ or Gpp(NH)p and was unaffected by catecholamine. In contrast, the effective concentration to achieve half-maximal activation for catecholamine activation was altered by guanine nucleotide; $\mathrm{Gpp}(\mathrm{NH}) \mathrm{p}\left(10^{-5} \mathrm{M}\right)$ but not $\mathrm{GTP}$, caused a shift (increased affinity) in catecholamine sensitivity from approximately $10^{-6}$ to $10^{-7} \mathrm{M}$ for (-)-epinephrine in both adult and fetal samples (data not shown). Lastly, dose responses of adenylate cyclase to catecholamines and the enhanced catecholamine activation of fetal myocardial adenylate cyclase by $\mathrm{Gpp}(\mathrm{NH}) \mathrm{p}$ were also determined in 24-hr-old (neonatal) rats (not shown) and were similar to those seen in fetal samples.

\section{DISCUSSION}

The present study demonstrates the developmental increase in ventricular $\beta$-adrenergic receptors, adenylate cyclase and $\mathrm{Na}^{+}$, $\mathrm{K}^{+}$-ATPase during growth of the rat myocardium. The specific activity of the $\beta$-receptor per mg protein decreases significantly with advancing age and is not directly related to the specific activity of other sarcolemmal markers, such as $\mathrm{Na}^{+}, \mathrm{K}^{+}$-ATPase or adenylate cyclase. Neither receptor affinity nor the ratio of $\beta_{1}$ to $\beta_{2}$-adrenergic subtypes (75:25) changes with advancing age. Guanine nucleotides decrease agonist affinity for the receptor site equally in fetal, neonatal, and adult ventricular membranes and are required for maximal catecholamine sensitive adenylate cyclase activation. This study also demonstrates possible subtle developmental differences in adenylate cyclase activation related to guanine nucleotides in the presence of catecholamines between fetal and weanling or adult ventricular membranes and confirms 
FETAL RAT HEART

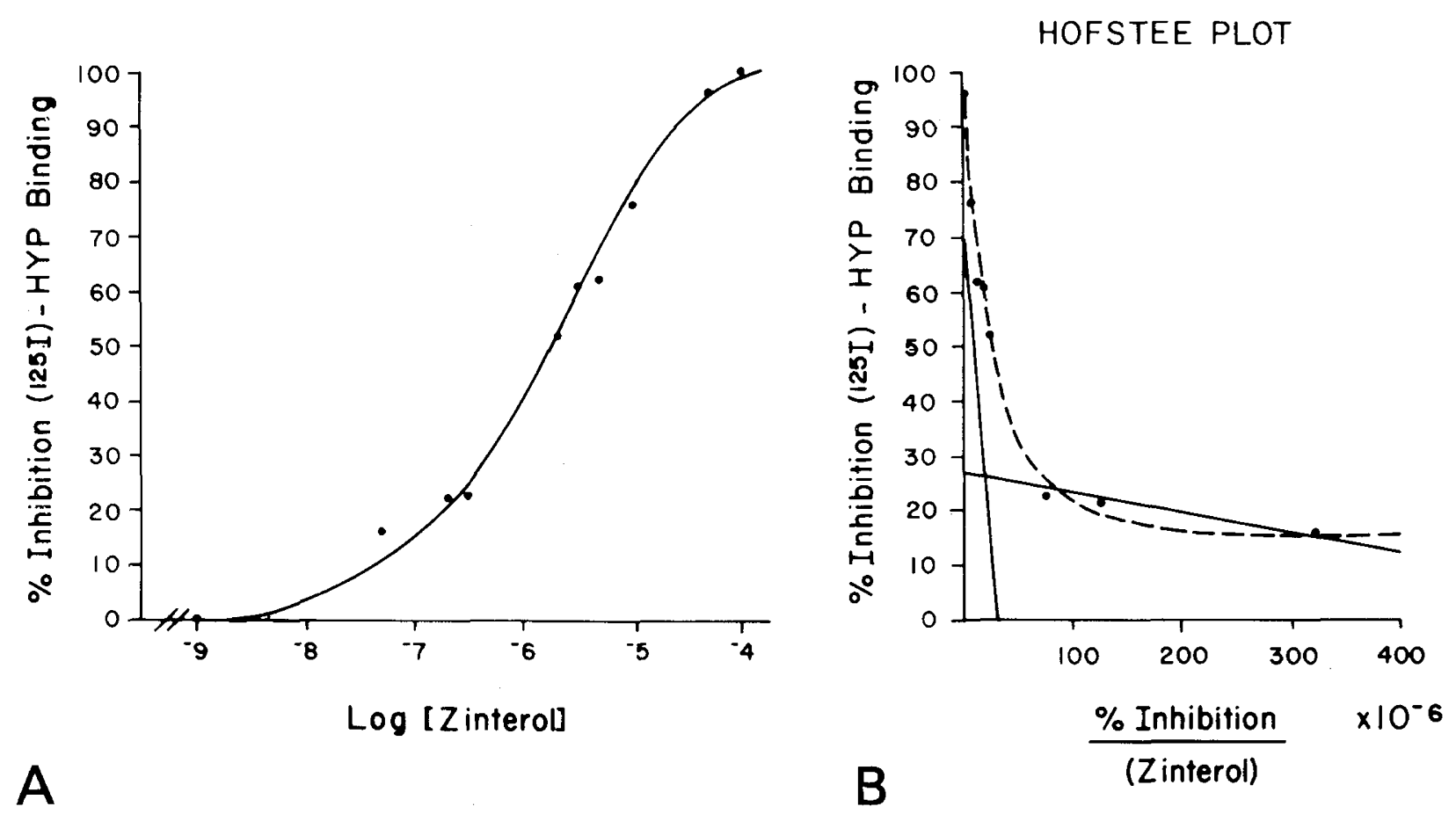

Fig. 4. Hofstee analysis of the inhibition of specific $( \pm)-\left[{ }^{125} \mathrm{I}\right] \mathrm{HYP}$ binding by the $\beta_{2}$-selective agonist zinterol in ventricular myocardium from fetal rat (day 21 of gestation). Points represent the mean of triplicate determinations, and the figure is representative of three separate experiments. Binding was determined in the presence of $100 \mu \mathrm{M}$ GTP, $100 \mathrm{pM}( \pm)-\left[{ }^{125} \mathrm{I}\right] \mathrm{H}$ YP as described in "Materials and Methods."

Table 3. Adenylate cyclase activity in 21-day fetal and weanling (90 g body weight) rat ventricular myocardium. ${ }^{1}$

\begin{tabular}{|c|c|c|}
\hline \multirow[b]{2}{*}{$\begin{array}{c}\text { Basal } \\
\left(\mathrm{pmoles} \cdot \mathrm{mg}^{-1} \cdot \mathrm{min}^{-1} \mathrm{cAMP}\right)\end{array}$} & \multicolumn{2}{|c|}{$\begin{array}{l}\text { Fold stimulation of } \\
\text { basal activity }\end{array}$} \\
\hline & $\begin{array}{c}\text { Weanling }(n=8) \\
13.4 \pm 1.4^{2}\end{array}$ & $\begin{array}{c}21 \text {-day } \\
\text { fetal }(n=8) \\
8.18 \pm 1.5\end{array}$ \\
\hline (-)Epinephrine & $2.50 \pm 0.18^{2,3}$ & $1.78 \pm 0.14$ \\
\hline (-)Epinephrine + GTP & $3.98 \pm 0.34^{2}$ & $2.93 \pm 0.23$ \\
\hline (-)Epinephrine $+\mathrm{Gpp}(\mathrm{NH}) \mathrm{p}$ & $7.04 \pm 0.64$ & $8.17 \pm 0.58^{4}$ \\
\hline $\operatorname{GTP}\left(10^{-5} \mathrm{M}\right)$ & $1.48 \pm 0.09$ & $1.72 \pm 0.14^{4}$ \\
\hline $\mathrm{Gpp}(\mathrm{NH}) \mathrm{p}\left(10^{-5} \mathrm{M}\right)$ & $4.55 \pm 0.52$ & $4.39 \pm 0.64$ \\
\hline $\mathrm{NaF}$ & $5.97 \pm 0.55$ & $5.97 \pm 0.59$ \\
\hline
\end{tabular}

${ }^{1}$ Adenylate cyclase was determined in triplicate in the presence and absence of $5 \times 10^{-5} \mathrm{M}$ (-)epinephrine, $10 \mathrm{mM} \mathrm{NaF}, 10^{-5} \mathrm{M} \mathrm{GTP}$, or $10^{-5}$ $M G p p(N H)$ p. Fold-stimulation is the specific activity in the presence of agonists divided by basal activity (absence of agonists).

${ }^{2}$ Weanling $>$ fetal; $P<0.001$.

${ }^{3}$ Mean \pm S.D. of eight adult and eight-fetal preparations on day 21 of a 22-day gestation; difference between the weanling and fetal values were assessed by Student's $t$ test.

${ }^{4}$ Fetal $>$ weanling, $P<0.01$.

the previous report of guanine nucleotide effects on catecholamine sensitive adenylate cyclase in developing rat myocardium (6).

Studies of catecholamine response in the developing myocardium have demonstrated the early appearance of a chronotropic effect, suggesting the functional relationship between the $\beta$-receptor and adenylate cyclase early in fetal development, occurring even before innervation in the chick heart $(1,18)$. In fact, maximal catecholamine-stimulated chronotropic responses by the mouse myocardium were demonstrated during the last day of gestation, decreasing postnatally (1). In the present study and as demon-

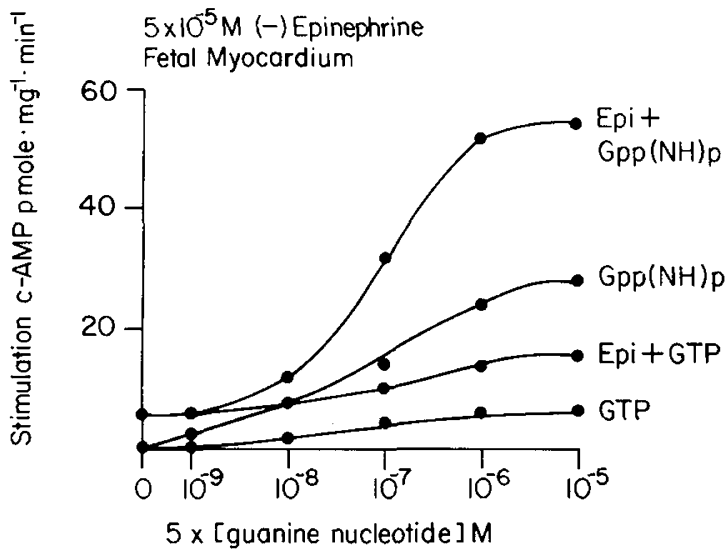

Fig. 5. (-)-Epinephrine-sensitive adenylate cyclase in fetal ventricular myocardium - effect of guanine nucleotides. Adenylate cyclase was determined in the presence and absence of $(-)$-epinephrine $\left(10^{-5} \mathrm{M}\right)$ in the presence of increasing concentrations of GTP or $10^{-5} \mathrm{M} G p p(\mathrm{NH})$ p. Stimulation represents activity, corrected for basal activity, in the presence and absence of catecholamines. Curves are representative of three to four similar experiments in the fetal and neonatal myocardium. The results of similar dose response curves with fetal and adult samples are summarized in Table 3 .

strated previously, the physiologic significance of the high $\beta$ adrenergic receptor binding activity in fetal rat heart is unclear and does not imply an increased physiologic response or sensitivity. The rat myocardium increases markedly in weight with advancing age, whereas cell number does not increase as dramatically after several weeks of age $(8,11,28)$. Thus, cell size increases and the proportion of sarcolemmal membrane protein to cell protein decreases with age as the surface area:cell volume ratio decreases. This increase in sarcolemmal surface area during hy- 
pertrophic growth in the rat myocardium has been demonstrated in older rats by direct measurement of isolated myocytes $(8,11$, $16,28)$. The observed decrease in $\beta$-adrenergic receptor binding assessed per unit protein which occurs in the developing rat myocardium is therefore likely to be influenced by the decreasing proportion of cellular protein contributed by the sarcolemma. Baker and Potter (2) have recently suggested that the number of $\beta$-adrenergic receptors per unit membrane area in rat myocardium from ages $2 \mathrm{wk}$ to 18 months remains constant and that cell surface area is the major determinant of $\beta$-adrenergic receptor number per cell. This latter study also demonstrates a decrease in the specific activity of $\beta$-adrenergic sites per unit weight and protein in the developing rat myocardium during this later time period.

In the present study, the specific activity (per mg protein) of sarcolemmal activities such as $\mathrm{Na}^{+}, \mathrm{K}^{+}$-ATPase, 5'-nucleotidase, and adenylate cyclase either remained nearly constant or increased with advancing age, and the increased activity (per heart) increased with changes in cell protein. (-) $\left.-{ }^{3} \mathrm{H}\right] \mathrm{DHA}$ binding activity did not increase as rapidly as adenylate cyclase or $\mathrm{Na}^{+}, \mathrm{K}^{+}$ATPase during growth. These latter activities regulate intracellular concentration dependent functions and we speculate that their concentration in the plasma membrane might therefore be determined by cell volume rather than the surface area of the myocytes. The specific activities and their relative changes with advancing age presently reported for $\mathrm{Na}^{+}, \mathrm{K}^{+}$-ATPase, $\beta$-adrenergic receptors, and adenylate cyclase are in close agreement with those previously reported $(2,6,10)$. Although we suggest that the specific activity of $\beta$-adrenergic receptor is related to sarcolemmal surface area, catecholamine receptors may also be modulated by hormonal influence or undergo maturational changes. For example, $\beta$-adrenergic receptors increase markedly with age in the developing rat lung and in the isolated myocyte after exposure to thyroid hormone $(22,24,26)$. The concentration of catecholamines to which the cell is exposed may also regulate $\beta$-adrenergic receptor number; however, the concentration of norepinephrine and epinephrine has been recently reported in the developing rat and are similar to adult levels on the last day of gestation, but fall abruptly postnatally (3). It is therefore unlikely that the higher specific activity of $\beta$-adrenergic sites in the fetal myocardium relates to a lack of exposure to agonists in late gestation.

The characteristics of the $\beta$-adrenergic sites presently demonstrated in fetal rat myocardium are similar in all ways to that in the adult. Thus, the $\beta_{1}$-adrenergic subtype, the pharmacologic characteristics of the sites, and the effects of GTP on decreasing agonist affinity were not different in fetal and adult samples. The predominance of $\beta_{1}$-adrenergic receptor subtype demonstrated by classical agonists is in close agreement with previous studies of adult rat myocardial $\beta$-receptors, and the $75 \%\left(\beta_{1}\right)$ to $25 \%\left(\beta_{2}\right)$ ratio as determined by selective $\beta$-adrenergic agents is in agreement with studies in adult rat heart (15).

In the present study, GTP markedly decreased agonist potency at $\beta$-adrenergic receptor sites and was required for full activation of the catalytic unit in adult myocardium. The effect of GTP in enhancing catecholamine stimulation was greater in the adult than fetal myocardium; however, the somewhat higher GTP stimulation of basal activity demonstrated in the fetal ventricular membranes complicates an interpretation of this observation. The smaller catecholamine-dependent component observed in the presence of GTP in the fetus may result from differences in the efficiency of coupling between receptor and the catalytic subunit or the stability of their components during membrane preparation. It does not appear to relate to residual catecholamine in the preparations as $10^{-7} \mathrm{M}$ alprenolol does not significantly inhibit basal activity in adult or fetal preparations. The enhanced catecholamine stimulated adenylate cyclase observed in the presence of $\mathrm{Gpp}(\mathrm{NH}) \mathrm{p}$ in fetal samples is not directly comparable to the synergistic effects with GTP because of the irreversible activation of the catalytic subunit by $\mathrm{Gpp}(\mathrm{NH}) \mathrm{p}$; the rate of $\mathrm{Gpp}(\mathrm{NH}) \mathrm{p}$ activation is enhanced by catecholamine; therefore, the higher percent stimulation of adenylate cyclase activity observed in fetal samples in the presence of $\mathrm{Gpp}(\mathrm{NH}) \mathrm{p}$ and catecholamine observed in this study cannot be directly correlated with the increased $\beta$ adrenergic receptor sites in the fetal preparations. The heightened response in fetal myocardial preparation to catecholamine and $\mathrm{Gpp}(\mathrm{NH}) \mathrm{p}$ presently reported was also observed in a recent study in late gestation fetal rat myocardium and suggests a difference between adult and fetal heart in the kinetic constants which are rate limiting for the activation of the catalytic subunit (16).

Lastly, the regulatory role of guanine nucleotides has, in general, not been included in previous studies of the ontogeny of various adenylate cyclase systems. The marked influence of low concentrations of guanine nucleotides in both receptor affinity and hormone-sensitive cAMP production emphasizes the need to assess the development of both receptor and adenylate cyclase under well defined conditions which include a concern for guanine nucleotide dependent factors.

\section{REFERENCES AND NOTES}

1. Adolph, E. F.: Ontogeny of heart-rate controls in hamster, rat and guinea pig. Am. J. Physiol., 220: 1896 (1971).

2. Baker, S. P., and Potter, L. T.: Cardiac $\beta$-adrenoreceptors during normal growth of male and female rats. Br. J. Pharmacol., 68: 65 (1980)

3. Ben-Jonathen, N.: Plasma catecholamines in fetal and neonatal rats. Life Sci., 23: 39 (1978).

4. Bilezikian, J. P., Speigel, A. M., Gammon, D. E., and Aurbach, G. D.: The role of guanyl nucleotides in the expression of catecholamine-responsive adenylate cyclase during maturation of the rat reticulocyte. Mol. Pharmacol., 13: 786 (1977).

5. Cassel, C., and Selinger, Z.: Mechanism of adenylate cyclase activation by choleratoxin: inhibition of GTP hydrolysis at the regulatory site. Proc. Natl. Acad. Sci. U. S. A., 74: 3307 (1977).

6. Clark, J. B., Vinicor, F., Carr, L., and Clark, C. M.: Adenyl cyclase responsiveness to guanyl nucleotides in the developing rat heart. Pediatr. Res., 14:291 (1980).

7. Colatart, D. I., Davis, G. M., Gillibrand, I. M., and Hames, J.: Adenyl cyclase activity in the developing human fetal heart. J. Physiol. (Lond.), 225: 38 (1972).

8. Grimm, A. F., de la Torre, L., and La Porta, M.: Ventricular nuclei-DNA relationships with myocardial growth and hypertrophy in the rat. Circ. Res., 26: 45 (1970).

9. Hegstrand, L. R., Minneman, K. P., and Molinoff, P. B.: Multiple effects of guanosine triphosphate on Beta adrenergic receptors and adenylate cyclase activity in rat heart, lung and brain. J. Pharmacol. Exp. Ther., 210: 215 (1979).

10. Inturrisi, C. E., and Papacastantinou, M. C.: Ouabain sensitivity of the $\mathrm{Na}^{+}, \mathrm{K}^{+}$ ATPase from rat neonatal and human fetal and adult heart. Ann. N. Y. Acad. Sci., 242: 710 (1974).

11. Korecky, B., and Rakusan, K.: Normal and hypertrophic growth of the rat heart: changes in cell dimension and number. Am. J. Physiol., 234: 123 (1978)

12. Maguire, M. E., Ross, E. M., and Gilman, A. G.: $\beta$-Adrenergic receptor: Ligand binding and interaction with adenylyl cyclase. Adv. Cyclic Nucleotide Res., 8 : 1 (1977).

13. Maguire, M. E., VanArdsdale, P. M., and Gilman, A. G.: An agonist-specific effect of guanine nucleotides on binding to $\beta$-adrenergic receptors. Mol Pharmacol., 12: 335 (1976).

14. Martin, S., Levey, B. A., and Levey, G. S.: Development of the cardiac Beta adrenergic receptor in fetal rat heart. Biochem. Biophys. Res. Commun., 54: 949 (1973).

15. Minneman, K. P., Hegstrand, L. R., and Molinoff, P. B.: Simultaneous determination of Beta-1 and Beta-2 adrenergic receptors in tissues containing both receptor subtypes. Mol. Pharmacol., 16: 34 (1979).

16. Page, E., and McCallister, L. P.: Quantitative electron microscopic description of heart muscle cells: application to normal, hypertrophic and thyroxine-stimulated hearts. Am. J. Cardiol., 31: 172 (1973).

17. Palmer, G. C., and Dail, W. G.: Appearance of hormone-sensitive adenylate cyclase in developing human heart. Pediatr. Res., 9: 98 (1975).

18. Polson, J. B., Goldberg, N. D., and Shideman, F. E.: Norepinephrine and isoproterenol induced changes in cardiac contractility and cyclic adenosine 3 : $5^{\prime}$-monophosphate levels during early development of the embryonic chick. $J$ Pharmacol. Exp. Ther., 200: 630 (1977).

19. Rodbell, M., Birnbaumer, L., Pohl, S. L., and Krans, H. M. J.: The glucagon sensitive adenylate cyclase in plasma membranes of rat liver. V. An obligatory role of guanyl nucleotides in glucagon action. J. Biol. Chem., 246: 1877 (1971)

20. Salomon, Y., Londos, C., and Rodbell, M.: A highly sensitive adenylate cyclase assay. Anal. Biochem., 58: 541 (1974).

21. Schneider, W. C.: Determination of nucleic acids in tissues by Pentose analysis. Methods Enzymol. 3: 680 (1957).

22. Tsai, J. S., and Chen, A.: Effect of L-triiodothyronine on $(-)^{3} \mathrm{H}$-dihydroalprenolol binding and cyclic AMP response to (-)adrenaline in cultured heart cells. Nature (Lond.), 275: 138 (1978).

23. Whitsett, J. A., Johnson, C. L., Darovec-Beckerman, C., and Costello, M.: $\beta$ Adrenergic receptors and catecholamine sensitive adenylate cyclase in human placenta. J. Clin. Endocrinol. Metab., 50: 27 (1980).

24. Whitsett, J. A., Manton, M., Darovec-Beckerman, C., and Adams, K.: $\beta$-Adrenergic receptors and catecholamine sensitive adenylate cyclase in developing rat lung. Life Sci., 28: 339 (1981). 
25. Whitsett, J. A., and Wallick, E. T.: $\mathrm{Na}^{+}, \mathrm{K}^{+}$-ATPase and $\left[{ }^{3} \mathrm{H}\right]$ ouabain binding in human placental membranes. Am. J. Physiol., 238: 1E38 (1980).

26. Williams, L. T., Lefkowitz, R. J., Watanabe, A. M., Hathaway, D. R., and Besch, H. R.: Thyroid hormone regulation of $\beta$-adrenergic receptor number. J. Biol. Chem. 252: 2787 (1977).

27. Yount, E. A., Clark, J. F., and Clark, C.: Development of guanylimidophosphatedependent activation of adenylate cyclase by glucagon in the neonatal rat heart. Pediatr. Res., 10: 851 (1976).

Copyright (C 1981 International Pediatric Research Foundation, Inc. $0031-3998 / 81 / 1510-1363 \$ 02.00 / 0$
28. Zak, R.: Cell proliferation during cardiac growth. Am. J. Cardiol., 31: 211 (1973). 29. The authors would like to thank Jane Hall and Jennifer Pollinger for their expert technical assistance.

30. Requests for reprints should be addressed to: Dr. Jeffrey A. Whitsett, Newborn Division of Pediatrics, University of Cincinnati College of Medicine, 231 Bethesda Ave., Cincinnati, OH 45627 (USA)

31. Received for publication September 11, 1980.

32. Accepted for publication February 2, 1981.

Printed in U.S.A. 